\title{
Exploring the Ecological History of a Tropical Agroforestry Landscape Using Fossil Pollen and Charcoal Analysis from Four Sites in Western Ghats, India
}

\author{
Sandra Nogué, ${ }^{1,2 *}$ Carolina Tovar, ${ }^{2,3}$ Shonil A. Bhagwat, ${ }^{4,5}$ \\ Walter Finsinger, ${ }^{6}$ and Kathy J. Willis ${ }^{2,3}$
}

\begin{abstract}
${ }^{1}$ Geography and Environment, University of Southampton, Highfield, Southampton SO17 1BJ, UK; ${ }^{2}$ Long-Term Ecology Laboratory, Department of Zoology, University of Oxford, Oxford OX1 3PS, UK; ${ }^{3}$ Royal Botanical Gardens, Kew, Richmond, Surrey TW9 3AE, UK;

${ }^{4}$ Department of Geography, and Open Space Research Centre, The Open University, Walton Hall, Milton Keynes MK7 6AA, UK;

${ }^{5}$ School of Geography and the Environment, University of Oxford, Oxford OX1 3QY, UK; ${ }^{6}$ Institut des Sciences de l'Evolution (UMR 5554 CNRS), University of Montpellier, 34095 Montpellier, France
\end{abstract}

\begin{abstract}
Contrary to expectations, some human-modified landscapes are considered to sustain both human activities and biodiversity over the long-term. Agroforestry systems are among these landscapes where crops are planted under native shade trees. In this context, ancient agroforestry systems can provide insight into how farmers managed the landscape over time. Such insight can help to quantify the extent to which tropical forests (especially habitat-specialist trees) are responding to local and landscape-level management. Here,
\end{abstract}

Received 5 June 2016; accepted 16 February 2017; published online 3 April 2017

Electronic supplementary material: The online version of this article (doi:10.1007/s10021-017-0132-1) contains supplementary material, which is available to authorized users.

Authors contributions All authors designed the study. SN, CT, and $\mathrm{WF}$ analysed the data. SN leads the writing, with contributions from all authors.

*Corresponding author; e-mail: s.nogue-bosch@soton.ac.uk we extracted fossil pollen (indicator of past vegetation changes) and macroscopic charcoal (indicator of biomass burning) from four forest hollows' sedimentary sequences in an ancient agroforestry system in Western Ghats, India. We used a mixed-modelling approach and a principal components analysis (PCA) to determine past trajectories of forest change and species composition dynamics for the last 900 years. In addition, we reconstructed the long-term forest canopy dynamics and examined the persistence of habitatspecialist trees over time. Our results show that the four sites diverged to a surprising degree in both taxa composition and dynamics. However, despite these differences, forest has persisted over 900 years under agricultural activities within agroforestry systems. This long-term analysis highlights the importance of different land-use legacies as a framework to increase the effectiveness of management across tropical agricultural lands.

Key words: agroforestry; charcoal; ecological history; fossil pollen; India; mixed-modelling; tropical forest. 


\section{INTRODUCTION}

In many tropical countries, agroforestry (that is, the practice of planting crops under shade trees) is an important strategy for forest management (McNeely and Schroth 2006; Bhagwat and others 2008). However, there are still significant knowledge gaps regarding the ability of agroforestry systems to maintain biodiversity across space and time (Foster and others 2003; Ranganathan and others 2008; Bhagwat and others 2008, 2012). Especially, given that recent results suggest that tropical forest systems seem to be recovering faster following larger infrequent events such as cyclones and earthquakes than following small-scale human-induced impacts such as burning (Cole and others 2014). These findings are particularly relevant in the old tropics where agricultural activities are thought to have started approximately 11,000 years ago and potentially leaving a historical legacy of past human impacts (e.g. Pimm and Raven 2000; Ellis and others 2010).

Palaeoecological research has provided fundamental insights into the impacts of land-use change on forest ecosystems (Dearing and others 2012; Willis and Birks 2006). For example, studies have suggested that after the introduction of a new landcover type there is often an increase in canopy opening, a decline in tree abundance, introduction of new taxa, community turnover, and/or local extinctions (e.g. Denham and others 2003; de Nascimento and others 2016). However, not all palaeoecological records reported large changes in the composition of forest taxa. For example, there is evidence that retention of tree cover under lowintensity land-use change can maintain forests in human-modified landscapes over hundreds of years (Ranganathan and others 2008).

In addition, palaeoecological records have also provided information on the replacement of certain tree taxa in favour of trees important for: timber production (e.g. New Forest, UK), gardening (e.g. Poor Knights islands, New Zealand), and daily household needs like the 'forest gardens' of the Maya peoples (e.g. Mesoamerican forest, Belize) (Grant and Edwards 2008; Ewers and others 2013; Wilmshurst and others 2014). Hence, the ability of forest cover to persist over long timescales when human activities have been dominant over hundreds of years deserves more attention. In particular, it is important to understand whether policies that encourage the development of agroforestry systems, such as shade-grown coffee plantations, are good strategies to maintain biodiversity across space and time (Gordon and others 2006; Bhagwat and others 2005b; Garcia and others 2010; Tscharntke and others 2011).

Many ideas about agroforestry systems as refuges of biodiversity have been discussed in the literature (e.g. Bhagwat and others 2008). For example, agroforests are often very small in size $(<10 \mathrm{ha})$ and resemble forest patches and they have drawn attention from the conservationists as reservoirs of biodiversity (FAO and JRC 2012). It has also been documented that the effective conservation of agroforests is assisting to protect important habitats where fauna could act as dispersal agents and ensure seed rain, and in turn, forest regeneration (Ricketts and others 2008). However, degradation of these forest patches has also been reported (e.g. Laurance and others 2007, 2011). For example, by excessive removal of tree cover and repeated use of fire, the forest structure, function, and dynamics might be altered beyond the capacity of these agroforests to fully recover. There are therefore many questions pertaining to the sustainability of agroforestry techniques to maintain biodiversity over time, and understanding the relationship between agroforestry, cultural landscapes, and longterm biodiversity remains an important knowledge gap.

To address this knowledge gap, we reconstructed the long-term vegetation dynamics of tree-covered landscapes in the Kodagu region in the Western Ghats of India. This is a region characterised by a mixture of extensive agroforestry plantations and forest patches. Shade-grown coffee plantations occupy much of the landscape, but this region also has a high density of sacred groves. These sacred groves are an example of community-based conservation, and they serve as refugia for many forest-dwelling species over the timescales of hundreds of years (Bhagwat and others 2014; Nogué and others 2016). The sacred groves are surrounded by coffee plantations where coffee is planted under shade trees (Bhagwat and others 2008; Garcia and others 2010; Tscharntke and others 2011). Therefore, it represents an excellent region to test agroforestry systems dynamics over multi-centennial timescales and its ability to sustain biodiversity in the landscape over time. We used a palaeoecological approach to analyse four sites in this tree-covered landscape to obtain information about past land-use change, canopy dynamics, composition of taxa, and trajectories of forest change. To do this, we extracted fossil pollen (indicator of past vegetation changes) and macro- 
scopic charcoal (indicator of biomass burning) from four forest hollows' sedimentary sequences covering the last 900 years. We have two specific objectives:

1. To examine the rate of temporal change in the composition of plant taxa in ancient agroforestry systems, we reconstructed trajectories of vegetation change to test whether forest taxa have been sustained in the presence of agricultural activities over the past 900 years.

2. To reconstruct patterns of structural change in forest over time, we used two measures obtained from the palaeoecological data: (a) canopy dynamics to measure canopy closure over time, and (b) long-term presence of habitatspecialist evergreen rainforest trees (particularly long-lived trees) that are indicators of low disturbance (Lowmand and Schowalter 2012).

\section{MeTHODS}

\section{Site Location}

Four sedimentary sequences were collected from small swamps at an altitude of $900 \mathrm{~m}$ a.s.l. within agroforestry landscapes on the eastern side of the Kodagu district, Karnataka, India (Figure 1; Table S1). We collected sedimentary sequences from two forest patches also known as sacred groves (sacred grove-1, and grove-2) and two from agroforests (agroforest-1 and agroforest-2). More information about the four study sites is included in Table S1. We selected these sites in an area of $30 \times 40 \mathrm{~km}^{2}$ with a minimum distance between them of $5.3 \mathrm{~km}$ and a maximum of $31 \mathrm{~km}$. Given their close proximity and based on previous studies, we made the assumption that the four sites have been subjected to the same climatic conditions at least over the last 1000 years (Gupta and others 2006).

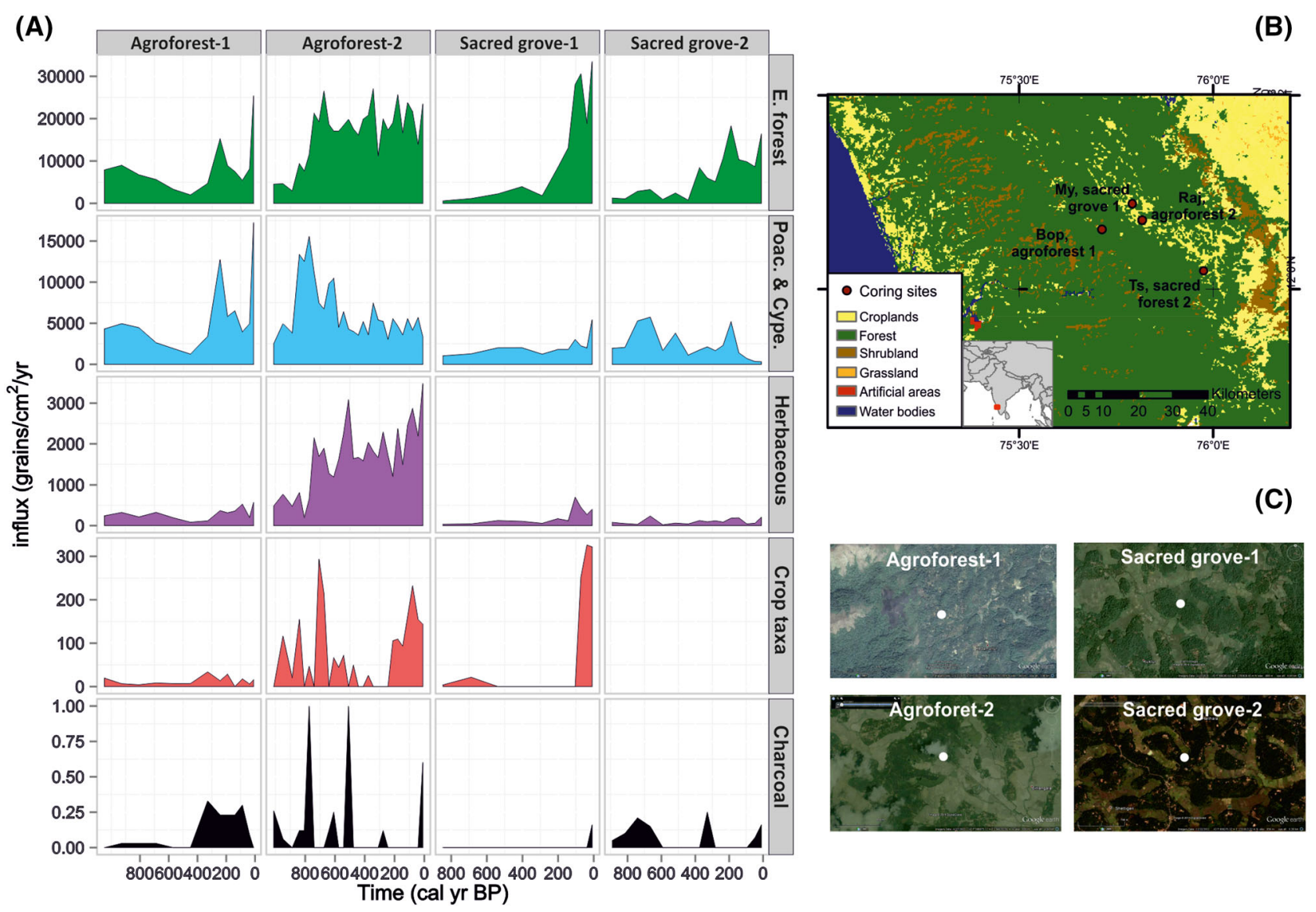

Figure 1. A Changes in influx of four vegetation types (crop taxa, evergreen forest, Poaceae and Cyperaceae, and other herbaceous). Charcoal influx values represented by particles $/ \mathrm{cm}^{2} / y$. E. forest: evergreen forest; Poac. and Cype: Poaceae and Cyperaceae (grassland). B Location of the four sites: two sites located in current agroforestry plantations (agroforest-1 and agroforest-2) and two sites in current sacred grove forests (Sacred grove-1 and grove-2). C Google map location of the 4 sites (scale, $1 \mathrm{~km}$ ). 


\section{Determining Age Chronology of Section: Radiocarbon and Lead -210 Dating}

A total of eleven samples were radiocarbon dated to determine the age-depth relationships for each sedimentary sequence (Figure S1). More details can be found in Bhagwat and others $(2012,2014)$ and in Table S4. In addition, the sections comprising the uppermost $8 \mathrm{~cm}$ of each sequence were dated using ${ }^{210} \mathrm{~Pb}$ at the University of Oxford (School of Geography and Environment). The sediment surfaces were given the age AD 2005, corresponding to the collection date (Table S4). Radiocarbon ages were calibrated using the IntCall 3 data set (Reimer and others 2013) to years before present (cal y BP). Age-depth relationships were established using Clam (Blaauw 2010).

\section{Reconstructing Vegetation and Fire Dynamics over Time: Fossil Pollen, Spores, and Charcoal Analysis}

Fossil pollen was extracted from samples taken at 4-cm intervals from each of the four sedimentary sequences following standard methodologies (Bennett and Willis 2001). Relative abundance of pollen taxa $(\%)$ was calculated as a proportion of the individual sum divided by the total land pollen sum ( $\Sigma$ TLP) (Figure S2, S3). Pollen influx (grains $/ \mathrm{cm}^{2} / \mathrm{y}$ ) was calculated for each taxon to demonstrate the relationship between pollen counts and past vegetation abundance taking into account variations in sedimentation rates (more details in Figure S2). We grouped the fossil taxa into four plant functional groups: evergreen forest (including e.g. trees, shrubs, and lianas), Poaceae and Cyperaceae (hereinafter referred to as grasslands), herbaceous (understory taxa, excluding Poaceae and Cyperaceae), and crop taxa (such as for example, Bentinckia, Coriandrium, Tamarindus). We separated grasses into two different functional groups to differentiate grassland vegetation from grasses from the forest understory. Full list of taxa is provided in supplementary information.

To trace the variation in biomass burning through time, we estimated the rate of charcoal accumulation (that is, the 'charcoal influx', denoted CHAR, charcoal particles $/ \mathrm{cm}^{3} / \mathrm{y}$ ), which accounts for changes in sedimentation rate and sediment compaction down-core (Whitlock and Larsen 2001). Contiguous sediment samples were processed and analysed following Finsinger and others (2014). Because it is highly likely that current fire-return intervals in the Western Ghats are significantly smaller ( $<15$ years; Kodandapani and others 2004) than the temporal resolution of our charcoal records, the variation in charcoal influx values we aimed to capture was those related to fire frequency and amount of biomass burned (Colombaroli and others 2014).

\section{Patterns of Forest Structural Changes}

Forest structural changes are difficult to measure and present a significant challenge to test using palaeoecological data. In our work, we approached it using two indices to help tracking over time changes in habitat-specialist trees indicators of low disturbance and canopy closure.

First, to analyse the long-term changes in local habitat-specialist trees we used the list of species that were surveyed during the period 1999-2001 on the study sites (Bhagwat and others 2005a, b). According to these surveys and the following published literature, we selected habitat-specialist trees indicators of sites with low disturbance (Table 1) (Daniels and others 1995; Ayyappan and Parthasarathy 1999; Muthuramkumar and others 2006). We then grouped the habitat-specialist tree species into 24 types where their pollen is identifiable to genus level: Aglaia, Artocarpus, Calophyllum, Cullenia, Dichapetalum, Dimocarpus, Dimorphocalyx, Dipterocarpus, Drypetes, Dysoxylon, Elaeocarpus, Holigarna, Hopea, Knema, Litsea, Mesua, Murraya, Myristica, Pallaquium, Poeciloneuron, Reinwardtiodendron, Strombosia, Symplocos, and Syzygium (Table 1). Within the tree genera such Artocarpus, while Artocarpus heterophyllus is commonly cultivated around human settlements for its edible fruits, the species that is commonly found in tree-covered landscapes are Artocarpus hirsuta. Although it is not possible to distinguish between the pollen of different species of Artocarpus under the light microscope, previous tree surveys from the study sites (Bhagwat and others 2005a, b) provide a robust basis for classifying Artocarpus as habitatspecialist tree taxa.

Second, to determine the degree of canopy closure, we calculated the relative proportion of arboreal pollen (AP) to non-arboreal pollen (NAP). This ratio has been demonstrated a reasonable index to assess the degree of canopy closure/ opening and therefore canopy cover (Svenning 2002).

\section{Forest Trajectories of Change}

To analyse trajectories of forest change, we analysed evergreen forest change through time using generalised mixed models (GAMM). We chose this 
Table 1. Habitat-Specialist Tree Species Corresponding to Local Pollen Taxa Indicative of Low Disturbance at the Four Study Sites in the Western Ghats Ancient Tropical Landscape

\begin{tabular}{|c|c|}
\hline Pollen taxon & Corresponding tree species \\
\hline Aglaia & Aglaia anamallayana; Aglaia jainii; Aglaia simplicifolia \\
\hline Artocarpus* & Artocarpus heterophyllus; Artocarpus hirsuta \\
\hline Calophyllum & Calophyllum polyanthum \\
\hline Cullenia & Cullenia exarillata \\
\hline Dichapetalum & Dichapetalum gelonioides \\
\hline Dimocarpus & Dimocarpus longan \\
\hline Dimorphocalyx & Dimorphocalyx lawianus \\
\hline Dipterocarpus & Dipterocarpus indicus \\
\hline Drypetes & Drypetes elata \\
\hline Dysoxylon & Dysoxylum malabaricum \\
\hline Elaeocarpus & Elaeocarpus serratus; Elaeocarpus tuberculatus \\
\hline Holigarna & Holigarna arnottiana; Holigarna beddomei; Holigarna grahamii; Holigarna nigra \\
\hline Hopea & Hopea ponga \\
\hline Knema & Knema attenuata \\
\hline Litsea & Litsea mysorensis; Litsea oleoides; Litsea stocksii \\
\hline Mesua & Mesua ferrea \\
\hline Murraya & Murraya koenigii \\
\hline Myristica & Myristica dactyloides \\
\hline Pallaqium & Palaquium ellipticum \\
\hline Poeciloneuron & Poeciloneuron indicum \\
\hline Reinwardtiodendron & Reinwardtiodendron anamalaiense \\
\hline Strombosia & Strombosia ceylanica \\
\hline Symplocos & Symplocos macrophylla \\
\hline Syzygium & $\begin{array}{l}\text { Syzygium gardnerii; Syzygium hemisphericum; Syzygium heyneanum; Syzygium mundagam; } \\
\text { Syzygium munronii; Syzygium phyllareoides; Syzygium zeylanicum }\end{array}$ \\
\hline \multicolumn{2}{|c|}{$\begin{array}{l}\text { Corresponding tree species are based on ecological surveys at the study sites conducted between } 1999 \text { and } 2001 \text { and reported in Bhagwat and others }(2005 a, b) \text { as sites: Topaij39 } \\
\text { agroforest-1; Pllsge08 (agroforest-2); Hglsge16 (sacred grove-1); Tslsg58 (sacred grove-2). } \\
* \text { * Present-day tree inventories suggest that the species of Artocarpus cultivated around human settlements (A. heterophyllus) for its edible fruit is different to the one more } \\
\text { commonly found in tree-covered landscapes (A. hirsuta). Although there are taxonomical limitations in pollen analysis, the present-day tree surveys from the study sites provide } \\
\text { a robust basis for classifying Artocarpus as habitat-specialist tree taxa. }\end{array}$} \\
\hline
\end{tabular}

approach to extract the main trend through time. We used evergreen forest influx as a dependent variable, while age, charcoal influx, grasslands (Poaceae and Cyperaceae), herbaceous taxa, crop taxa influx, and the ratio between arboreal and nonarboreal pollen influx (AP/NAP ratio) were used as independent variables. To incorporate data from the four sites into the model, we averaged the pollen and charcoal influx within 50-year bins to make the data comparable. Transformations were applied when necessary to meet the normality assumption. We performed a linear regression and given that we detected nonlinearity of the residuals against time we used a GAMM where age was treated as a smooth term and site as a random term. Given the heterogeneity of variance found in the residuals, we incorporated into the model a variance structure per current land management type (sacred groves vs agroforests). The selection of the most adequate variance structure was based on its best performance using AIC values (Table S2). No temporal autocorrelation was found in the data. Models were performed in R using the mgcv package (Table S2).

Changes in trajectories of composition of taxa though time were analysed performing a principal components analysis (PCA) in CANOCO 4.5 (ter Braak 1986). Pollen percentages were square-roottransformed and centred by taxa (functional groups). We performed ordination biplots showing the trajectory of change (series of samples) where the initial composition is represented by a circle and the present composition represented by an arrow.

\section{Results}

\section{Pollen Community Composition}

Our results indicated that agroforest- 1 displayed a decrease in forest influx between 900 years ago 
until around $400\left(<10,000\right.$ grains $\left./ \mathrm{cm}^{2} / \mathrm{y}\right)$ when a slight recovery can be observed towards the present time (maxima of 25,000 grains $/ \mathrm{cm}^{2} / \mathrm{y}$ ). On the contrary, the influx of forest pollen taxa showed an increase at 800 years in the agroforest- 2 site (from 200 to 25,000 grains $/ \mathrm{cm}^{2} / \mathrm{y}$ ) while the two sacred sites displayed low influx until 300 years ago when pollen influx increased (from 100 to 30,000 grains/ $\mathrm{cm}^{2} / \mathrm{y}$ ). In addition, pollen taxa indicative of agricultural activities (for example, Coffea and Plantago) appeared in three sites (agroforests and sacred grove-1) (Figure 1; Figure S3). Agroforest-1 is the only site where cultivated species were present continuously, albeit at low abundance, over the last 900 years. At agroforest- 2 and sacred grove- 1 , the abundance of cultivated pollen peaked twice: about 600 years ago and during the past $1-2$ centuries. At the sacred grove-2, there was no presence of cultivated taxa. Grassland pollen (Poaceae and Cyperaceae) was abundant at both agroforests. Other herbaceous pollen taxa displayed a low abundance at three sites (agroforest-1, and sacred groves) and an increasing trend in agroforest- 2 .

\section{Forest Structural Change}

The relative proportion of arboreal pollen (AP) to non-arboreal pollen (NAP) known as the index of canopy closure showed a shift from an open landscape to a forested habitat in sacred groves during the past 300 years (Figure 2). In contrast, both agroforests experienced either no major canopy change (agroforest-1) or only a slight canopy closing before 600 years ago (agroforest-2).

Pollen influx of habitat-specialist trees, indicative of sites with low disturbance, showed a steep increase in both sacred groves at around 300400 years ago (Table 1; Figure 2). In agroforests, abundance of these pollen taxa was either high for the last 700 years (agroforest-2) or low throughout the record (agroforest-1).

\section{Fire History}

Charcoal influx records did not show a general common pattern suggesting that periods of high biomass burning occurred at different times (Figure 1). For example, agroforest-1 displayed high biomass burning during the last 400 years $\left(0.25\right.$ grains $\left./ \mathrm{cm}^{2} / \mathrm{y}\right)$, whereas agroforest-2 displayed two peaks at 800 and $450 \mathrm{cal}$. years BP (1 charcoal $/ \mathrm{cm}^{2} / \mathrm{y}$ ) and another peak recently in the last $100-50$ years $\left(0.60 \mathrm{charcoal} / \mathrm{cm}^{2} / \mathrm{y}\right)$. Charcoal influx values in sacred groves were overall lower than in agroforests. The sacred grove-1 remained virtually protected from burning at least until 50 years ago when cultivated pollen taxa first appeared, while sacred grove- 2 burned mostly when the canopy was open, that is, before about 700 years ago $\left(0.25 \mathrm{charcoal} / \mathrm{cm}^{2} / \mathrm{y}\right)$.

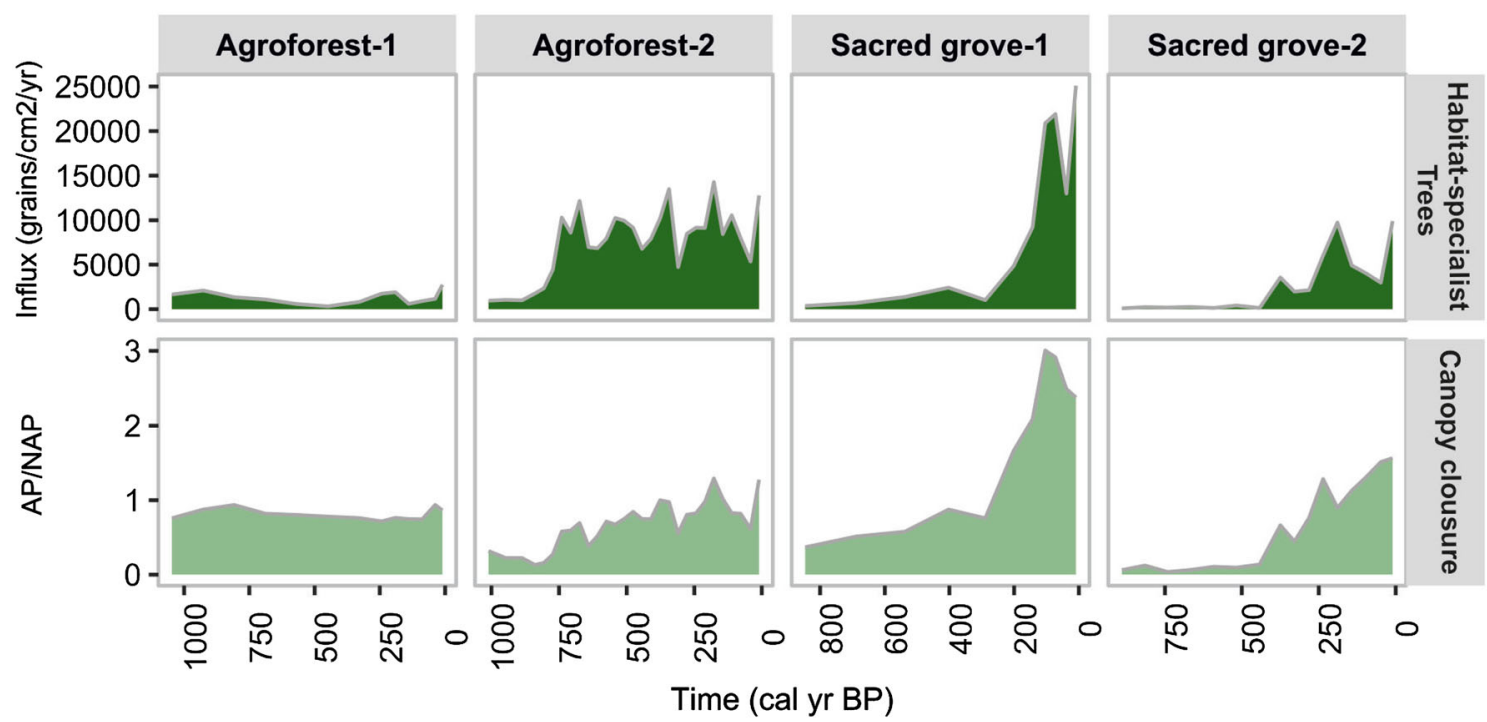

Figure 2. A Pollen influx of habitat-specialist tree taxa corresponding to local pollen taxa indicative of low disturbance at each site (details in supplementary information); B changes in canopy closure index (AP/NAP ratio). For the AP/NAP ratio values closer to 0 represent an open canopy, values around 1 represent about $50 \%$ of open canopy, while values above 1 represent greater canopy closure. 


\section{Forest Trajectories of Change}

The additive model showed that forest taxa experienced two contrasting types of trajectories of change between sites over the last 900 years: significant linear and nonlinear relationship with time (Figure 3A; Table 2). First, both agroforests showed nonlinear trends between forest influx and time. In agroforest-1, a U-shaped pattern was observed with a decrease at around 400 years ago and then a recovery, while in agroforest-2 we observed a hump-shaped pattern with an increase around 400 years ago and then a decline (Figure 3A). On the contrary, sacred groves showed a positive linear relationship between time and the abundance of forest pollen influx. This indicates an increasing trend of forest through present times. Only sacred grove- 2 showed a statistically significant positive linear relationship. In addition, we found a significant negative relationship between charcoal and evergreen forest pollen influx, suggesting that a decrease in biomass burning leads to an increase in evergreen forest (Table 2). Finally, we also found a positive relationship between the pollen influx of forest and other functional groups (Table 2).

Second, the analysis of change in taxa composition using the ordination PCA biplot showed different patterns for each site (Figure 3B). Axis 1 represents a gradient from Poaceae and Cyperaceae grasslands on the left (correlation coefficient = -0.9976 ) to forest taxa on the right (correlation coefficient $=0.9846$ ), while Axis 2 has a high positive correlation with herbaceous taxa (correlation coefficient $=0.9764)$. Main results showed that while agroforest-1 remained mainly constant over time, agroforest- 2 revealed a highly dynamic trajectory, moving from grasslands to evergreen forest and herbaceous taxa over this time. The two current sacred grove forest patches displayed a clear gradual change from grassland towards evergreen taxa.

\section{Discussion}

\section{Land Management and Patterns of Forest Structural Change}

The current rate of deforestation in tropical regions constitutes a major global biodiversity crisis (Lamb and others 2005). Here, we have analysed 900 years of ecological history in one of the most densely populated biodiversity hotspots where the expansion of conservation areas is limited by the competing pressures from other more productive land uses (Myers and others 2000; Cincotta and others 2000; Jha and others 2000; Newbold and others 2015). Studies dealing with the quantification
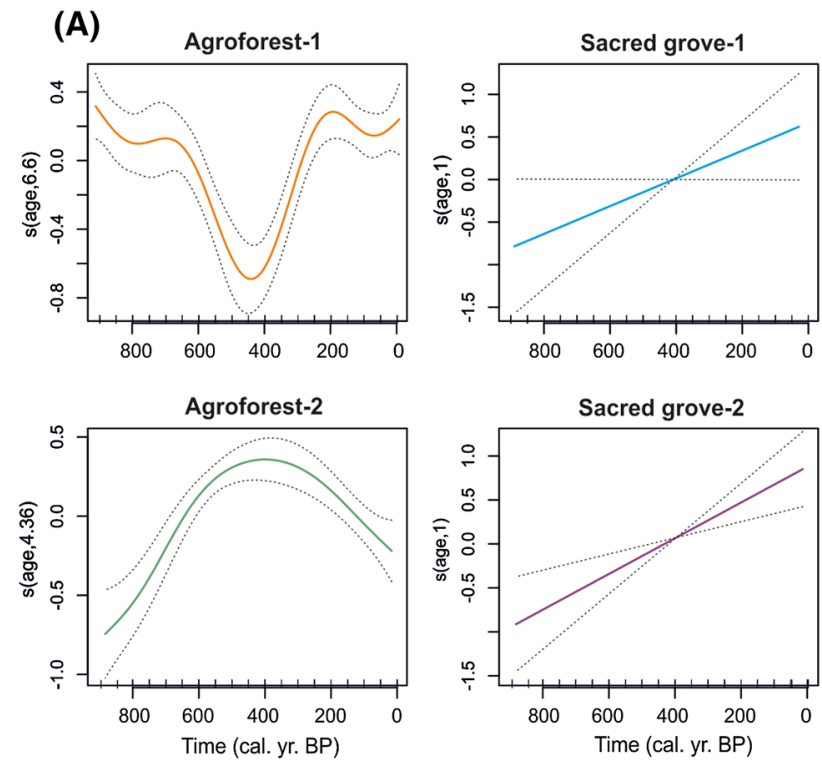

(B)

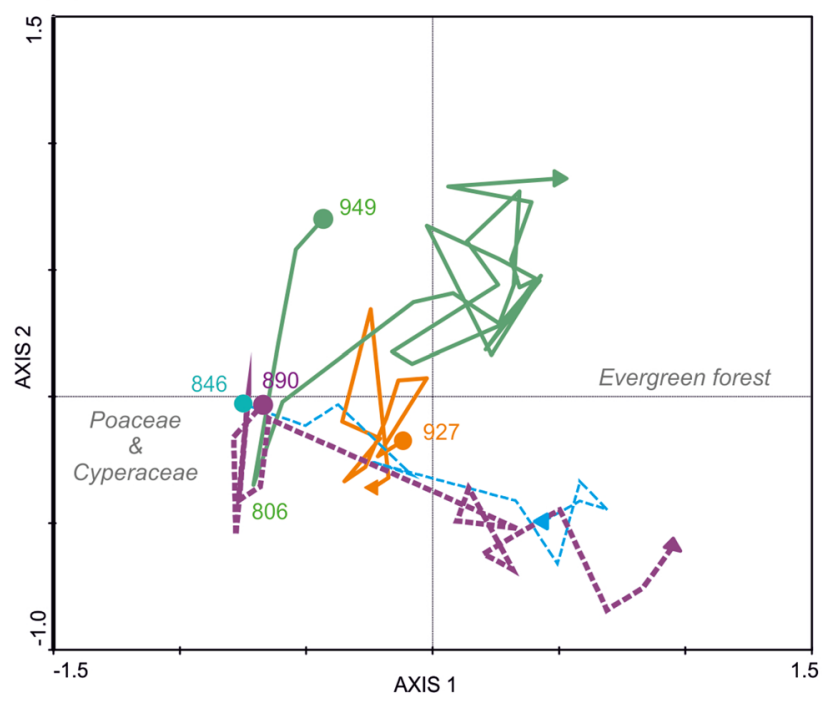

Figure 3. A GAMM model for forest over time showing the different trajectories of change for each site. B Ordination biplot of the PCA showing the trajectories of change in taxa composition of the two current sacred groves (dashed lines) and the two current agroforests (solid lines). The solid circle represents the initial taxa composition where the date (cal. years BP) is noted. Additionally, the date when the taxa composition of agroforest- 2 is similar to that of the sacred groves is also noted. Axis 1 explains $84 \%$ of the species composition, while Axis 2 explains $12 \%$. Axis 1 represents a gradient from grassland taxa (left) to evergreen forest. 
Table 2. Results of the Best GAMM Model for Evergreen Forest Influx Against Charcoal Influx (Charcoal), Poaceae and Cyperaceae Influx, Other Herbaceous Influx, Crop Taxa, and Canopy Closure Index (AP/NAP Ratio) as Fixed Variables and Time (50-Year Bin) per Site as Smooth Terms

\begin{tabular}{|c|c|c|c|c|}
\hline & Estimate & SE & $t$ value & $\operatorname{Pr}(>|t|)$ \\
\hline \multicolumn{5}{|l|}{ Parametric coefficients } \\
\hline (Intercept) & $7.56 \mathrm{E}+00$ & $2.42 \mathrm{E}-01$ & 31.275 & $<2 \mathrm{e}-16$ \\
\hline Charcoal & $-3.01 \mathrm{E}-01$ & $1.20 \mathrm{E}-01$ & -2.507 & 0.01697 \\
\hline Poaceae and Cyperaceae & $9.91 \mathrm{E}-05$ & $1.03 \mathrm{E}-05$ & 9.649 & $2.12 \mathrm{E}-11$ \\
\hline Herbaceous taxa & $2.22 \mathrm{E}-04$ & $6.76 \mathrm{E}-05$ & 3.28 & 0.002351 \\
\hline Crop taxa & $2.23 \mathrm{E}-03$ & $5.97 \mathrm{E}-04$ & 3.735 & 0.000665 \\
\hline \multirow[t]{2}{*}{ AP/NAP ratio } & $7.32 \mathrm{E}-01$ & $1.67 \mathrm{E}-01$ & 4.391 & $9.91 \mathrm{E}-05$ \\
\hline & edf & Ref. df & $F$ & $p$ value \\
\hline \multicolumn{5}{|c|}{ Approximate significance of smooth terms (s(age):site) } \\
\hline Agroforest-1 & 6.602 & 6.602 & 9.242 & $7.30 \mathrm{E}-07$ \\
\hline Sacred site-1 & 1 & 1 & 3.943 & 0.054803 \\
\hline Agroforest-2 & 4.356 & 4.356 & 16.877 & $3.61 \mathrm{E}-09$ \\
\hline Sacred site- 2 & 1 & 1 & 13.315 & 0.000817 \\
\hline
\end{tabular}

of human impacts over the recent past show that between 1920 and 1990 the Western Ghats experienced $40 \%$ decline in forest cover and $83 \%$ reduction in average of patch area (Menon and Bawa 1997). In addition, a study analysing the spatial data on fire occurrence between 1989 and 2002 suggests that the increasing occurrence of fires in the Western Ghats poses a severe and persistent conservation threat to forests both within and outside protected areas (e.g. Kodandapani and others 2004). In this context, it has been suggested that agroforestry systems have recently emerged as one of the most promising approaches to reducing deforestation in the tropics while enhancing rural livelihoods (Bhagwat and others 2008).

Our charcoal and pollen analysis suggests that during the last 900 years fire was commonly used in this region (Figure 1). For example, we found the irregular occurrence of pollen taxa indicator of agricultural activities such as Plantago, Tamarindus, and Coffea together with the presence of charcoal. We interpret the variations of charcoal influx as an indicator of burning as part of agricultural activities. However, a relevant result is that even when the landscape was showing strong signs of mixed shifting cultivation, trees were still present in the landscape but in low abundance (Figures 1, 2). To further analyse the implications of these results and to provide more details on forest structural change, we selected two indexes: (1) the closeness of the forest canopy (AP/NAP ratio), and (2) the abundance of habitat-specialists trees from the genera e.g. Dipterocarpus, Diospyros, Hopea, and $\mathrm{Pa}$ laquium (Table 1), which are considered good indicators of sites with low disturbance and are a priority in the conservation planning of the region (Muthuramkumar and others 2006). Our results showed that 900 years ago, the landscape was open with low canopy closure index values $(<1$ in all four sites, Figure 2), and low abundance of habitat-specialists trees $\left(<2000\right.$ grains $/ \mathrm{cm}^{2}$ year $)$. However, the source of the tree pollen found during this period might be attributed to both potential nearby, large forest masses beyond the agricultural lands and from the smaller and fragmented forest patches within the agricultural landscape. A recent phytolith analysis (that is, the opaline silica bodies from plant tissues) carried out in two of the study sites (agroforest-1 and sacred grove-1) is useful in the interpretation of this result (Nogué and others 2016). Phytoliths are known to be an excellent proxy to investigate the presence of vegetation, especially grasses, at a local scale (Barboni and others 1999). This paper showed that the local presence of tree taxa concur (with a slight temporal delay) with the tree pollen time-series (Bhagwat and others 2012, 2014). Such concurrence between these two different palaeoecological proxies makes us confident that the pollen signal we are recovering from the sedimentary cores is from the forest patch remaining in the agricultural land. 
The period of low presence of trees in the landscape lasted approximately 250 years when there was an increase in both forest canopy and habitatspecialist trees. Finally, we found that in sacred groves habitat-specialist trees displayed an increasing trend during the last 200 years, in parallel to canopy closure index. These results suggest that the current landscape configuration of forest patches (some of them sacred groves), and paddy cultivation fields, is truly ancient (e.g. 400 years) and that farmers have actively managed the landscape by reducing but also by maintaining the number of trees in the landscape. One example is the establishment of sacred groves that are known to be protecting trees dedicated to the worship (Bhagwat and Rutte 2006). The long-term history of sacred groves could be indicating that farmers may have protected habitat-specialist trees from fires and other major disturbances associated with the change in land-use from forest to agriculture (Chazdon 2003; Bhagwat and others 2014). In addition, an examination of sociocultural drivers of forest recovery in the past has suggested that forest recovery may have taken place due to the values attached to tree-covered landscapes. Particularly ecosystem service provision from forests (Bhagwat and others 2014). The high tree cover in the present-day landscape (over $60 \%$ of the landscape is under shade-grown coffee cultivation; see Bhagwat and others 2005a, b) is also indicative of the value attached to trees in shade-grown coffee cultivation today.

\section{Temporal Change in Taxa Composition in Ancient Agroforestry Systems}

This palaeoecological study shows that the landscape in this region is highly dynamic displaying strongly divergent trends at local scale in terms of taxa composition and trajectories of forest change (Figures 1 , $2,3)$. By using the smooth term of the GAMM, we were able to extract the main trend of the trajectories of change and we found both nonlinear trajectories (agroforests) and linear trajectories (sacred groves) of forest change over time. For example, the agroforest- 1 site has remained as a mixed shifting cultivation fallow with small changes in taxa composition during the whole time-period (excluding the last 10 years), presumably due to the influence of frequent burning activities (Figures 1, $3)$. In contrast, the sacred grove- 2 site displays a gradual change from grassland towards evergreen forest with the highest increase occurring during the last 400 years (Figures 1, 3).
Changes in taxa composition also support the trajectories of forest change (Figure 2B). With the ordination PCA biplot, we show that although vegetation composition of agroforest-1 remains mainly constant over time, composition of agroforest-2 reveals a highly dynamic trajectory of change, moving from Poaceae and Cyperaceae grasses (grasslands) to evergreen forest and other herbaceous taxa over time. On the contrary, the two current sacred groves display a clear gradual change from grassland towards evergreen taxa. As such, high dynamism and divergence are likely to be common features of tropical agroforestry systems where human intervention could promote both linear and nonlinear trajectories of forest change, that is, by actively removing and/or maintaining trees. Although further progress is required to determine a consistent global trend across tropical agroforestry systems, our results suggest that the divergent trajectories of change might have promoted the maintenance of biodiversity within the landscape scale (Penne and others 2010; Ewers and others 2013).

A limitation encountered in this study is that although we found a negative relation between forest and charcoal which shows the negative effect of burning related to agricultural activities on forest (Table 2), our analysis does not capture other landclearing mechanisms. For example, in sacred grove-1 we found grassland dominance in the absence of fire, thus making the role of human protection less obvious. An alternative hypothesis such as logging could explain the initial grassland dominance in sacred groves. However, this type of data is difficult to obtain from the long-term records. What we can confirm, however, is a strong evidence for the historical maintenance of both agroforests and sacred groves (and potentially other forest patches) for 900 years in this region despite widespread use of fire by ancient farmers (Figure 1).

\section{Conclusions}

We have shown that humans might have actively removed but also maintained trees both in agricultural landscapes and in sacred groves in the Western Ghats during the last 900 years and thus the sustainability of its biodiversity. In addition, human activities and disturbances were insufficient to prevent long-term forest recovery and regeneration, following cessation of cultivation activities and grassland burning. However, the results suggest that natural forest recovery processes may 
have been aided by fire suppression and protection of nearby evergreen forest patches by humans. Our study showed that the Western Ghats landscape is an appropriate model system to study the historical management of agroforestry lands over time.

Although we cannot draw general conclusions about global historical land-use changes in tropical agroforestry landscapes, our study does provide an initial glimpse of trajectories of forest change. For example, while providing new evidence on the temporal dynamics of agricultural lands, we have shown that agroforests are responding differently to local disturbances. Finally, studies like this provide frameworks for increasing the effectiveness of forest management in tropical countries (Swetnam and others 1999).

\section{ACKNOWLEDGEMENTS}

This research was supported by the Leverhulme Trust Grant (F/08 773/E), the British Ecological Society, and the Norwegian Academy of Science and Letters through the VISTA programme (6158) through a postdoctoral fellowship to SN. We are thankful to C. Cornwell and S. Subitani for help with some of the charcoal analysis, Matt Telfer for support with the ${ }^{210} \mathrm{~Pb}$, and $\mathrm{A}$. Smith and $\mathrm{P}$. Langdon for comments on an early version of this manuscript. We also thank T. Brncic for help with coring, C.G. Kushalappa and the College of Forestry for field assistance. R. Premathilake, K. Anupama, S. Prasad and the Palynology Laboratory at the French Institute, Pondicherry, for help with identification. S. Harris and the University of Oxford's Plant Sciences Herbarium for access to reference collections.

\section{OPEN ACCESS}

This article is distributed under the terms of the Creative Commons Attribution 4.0 International License (http://creativecommons.org/licenses/by/ 4.0/), which permits unrestricted use, distribution, and reproduction in any medium, provided you give appropriate credit to the original author(s) and the source, provide a link to the Creative Commons license, and indicate if changes were made.

\section{REFERENCES}

Ayyappan N, Parthasarathy N. 1999. Biodiversity inventory of trees in a large-scale permanent plot of tropical evergreen forest at Varagalaiar, Anamalais, Western Ghats, India. Biodivers Conserv 8:1533-54.

Barboni D, Bonnefille R, Alexandre A, Meunier JD. 1999. Phytoliths as paleoenvironmental indicators, West Side Mid- dle Awash Valley, Ethiopia. Palaeogeogr Palaeoclimatol Palaeoecol 152:87-100.

Bennett KD, Willis KJ. 2001. Pollen. Volume 3: terrestrial, algal, and siliceous indicators. In: Smol JP, Birks HJB, Last WM, Eds. Tracking environmental change using lake sediments. Dordrecht: Springer.

Bhagwat S, Kushalappa C, Williams P, Brown N. 2005a. The role of informal protected areas in maintaining biodiversity in the Western Ghats of India. Ecol Soc 10(1):8. [online] URL: http:// www.ecologyandsociety.org/voll0/iss1/art8/

Bhagwat SA, Kushalappa CG, Williams PH, Brown ND. 2005b. A landscape approach to biodiversity conservation of sacred groves in the Western Ghats of India. Conserv Biol 19(6):1853-62.

Bhagwat SA, Rutte C. 2006. Sacred groves: potential for biodiversity management. Front Ecol Environ 4:519-24.

Bhagwat SA, Willis KJ, Birks HJB, Whittaker RJ. 2008. Agroforestry: a refuge for tropical biodiversity. Trends Ecol Evol 23:261-7.

Bhagwat SA, Nogué S, Willis KJ. 2012. Resilience of an ancient tropical forest landscape to 7500 years of environmental change. Biol Conserv 153:108-17.

Bhagwat SA, Nogué S, Willis KJ. 2014. Cultural drivers of reforestation in tropical forest groves of the Western Ghats of India. For Ecol Manag 329:393-400.

Blaauw M. 2010. Methods and code for 'classical' age-modelling of radiocarbon sequences. Quat Geochronol 5:512-18.

Chazdon RL. 2003. Tropical forest recovery: legacies of human impact and natural disturbances. Perspect Plant Ecol Evol Syst 6:51-71.

Cincotta RP, Wisnewski J, Engelman R. 2000. Human population in the biodiversity hotspots. Nature 404:990-2.

Cole LES, Bhagwat SA, Willis KJ. 2014. Recovery and resilience of tropical forests after disturbance. Nat Commun 5:3906. doi:10.1038/ncomms4906.

Colombaroli D, Ssemmanda I, Gelorini V, Verschuren D. 2014 Contrasting long-term records of biomass burning in wet and dry savannas of equatorial East Africa. Global Change Biol 20:2903-14.

Daniels RJR, Gadgil M, Joshi NV. 1995. Impact of human extraction on tropical humid forests in the Western Ghats Uttara Kannada, South India. J Appl Ecol 32:866-74.

Dearing JA, Bullock S, Contanza R, Dawson TP, Edwards ME, Poppy GM, Smith GM. 2012. Navigating the perfect storm: research strategies for social-ecological systems in a rapidly evolving world. Environ Manag 49(4):767-75.

Denham TP, Haberle SG, Lentfer R, Field J, Therin M, Porch N, Winsborough B. 2003. Origins of agriculture at Kuk swamp in the highlands of new guinea. Science 301:189-93.

de Nascimento L, Nogué S, Criado C, Ravazzi C, Whittaker RJ, Willis KJ, Fernández Palacios JM. 2016. Reconstructing Holocene vegetation on the island of Gran Canaria before and after human colonization. The Holocene 1:113-25.

Ellis EC, Goldewijk K, Siebert S, Lightman D, Ramankutty N. 2010. Anthropogenic transformation of the biomes, 1700 to 2000. Global Ecol Biogeogr 19:589-606.

Ewers RM, Didham RK, Pearse WD, Lefebvre V, Rosa IMD, Carreiras JMB, Lucas RM, Reuman DC. 2013. Using landscape history to predict biodiversity patterns in fragmented landscapes. Ecol Lett 16:1221-33.

FAO and JRC (2012) Global forest land-use change 1990-2005, by E.J. Lindquist, R. D'Annunzio, A. Gerrand, K. MacDicken, 
F. Achard, R. Beuchle, A. Brink, H.D. Eva, P. Mayaux, J. SanMiguel-Ayanz \& H-J. Stibig. FAO Forestry Paper No. 169. Food and Agriculture Organization of the United Nations and European Commission Joint Research Centre. Rome, FAO.

Finsinger W, Kelly R, Fevre J, Magyari EK. 2014. A guide to screening charcoal peaks in macrocharcoal-area records for fire-episodes reconstructions. The Holocene 24:1002-8.

Foster D, Swanson F, Aber J, Burke I, Brokaw N, Tilman D, Knapp A. 2003. The importance of land-use legacies to ecology and conservation. BioScience 53:77-88.

Garcia CA, Bhagwat SA, Ghazoul J, Nath CD, Nanaya KM, Kushalappa CG, Raghuramulu Nasi R, Vaast P. 2010. Biodiversity conservation in agricultural landscapes: challenges and opportunities of coffee agroforests in the Western Ghats, India. Conserv Biol 24(2):479-88.

Grant MJ, Edwards ME. 2008. Conserving idealized landscapes: past history, public perception and future management in the New Forest (UK). Veg Hist Archaeobotany 17:551-62.

Gupta AK, Anderson DM, Pandey DN, Singhvi AK. 2006. Adaptation and human migration and evidence of agriculture coincident with changes in the Indian summer monsoon during the Holocene. Curr Sci 90:1082-90.

Gordon C, Manson R, Sundberg J, Cruz-Angon A. 2006. Biodiversity, profitability, and vegetation structure in a Mexican coffee agrosystem. Agric Ecosyst Environ 118:256-66.

Jha CS, Dutt CBS, Bawa KS. 2000. Deforestation and land-use changes in Western Ghats, India. Current Science 79:231-7.

Kodandapani N, Cochrane MA, Sukumar R. 2004. Conservation threat of increasing fire frequencies in the Western Ghats, India. Conserv Biol 18:1553-61.

Lamb David, Erskine Peter D, Parrotta John A, Lamb D, Erskine PD, Parrotta JA. 2005. Restoration of degraded tropical forest landscapes. Science 310:1628-32.

Laurance WF, Camargo JLC, Luizão RCC, Pimm S, Lovejoy T, Zartman CE. 2011. The fate of Amazonian forest fragments: a 32-year investigation. Biol Conserv 144:56-67.

Laurance WF, Nascimento HEM, Laurance SG, Andrade A, Ewers RM, Harms KE, Luizão RCC, Ribeiro JE. 2007. habitat fragmentation, variable edge effects, and the landscape-divergence hypothesis. PLoS ONE 2:e1017.

Lowmand MD, Schowalter TD. 2012. Plant science in forest canopies: the first 30 years of advances and challenges (19802010). New Phytol 194:12-27.

McNeely JA, Schroth G. 2006. Agroforestry and conservation: traditional practices, present dynamics, and lessons for the future. Biodivers Conserv 15:549-55.

Menon S, Bawa KS. 1997. Applications of geographic information systems, remote-sensing, and a landscape ecology approach to biodiversity conservation in the Western Ghats. Curr Sci 73:134-45.

Muthuramkumar S, Ayyappan N, Parthasarathy N, Mudappa D, Raman TRS, Selwyn MA, Pragasan LA. 2006. Plant community structure in tropical rain forest fragments of the Western Ghats, India. Biotropica 38:143-60.

Myers N, Mittermeier RA, Mittermeier CG, Da Fonseca GAB, Kent J. 2000. Biodiversity hotspots for conservation priorities. Nature 403:853-8.
Newbold T, Hudson LN, Hill SLL, Contu S, Lysenko I, Senior RA, Borger L, Bennett DJ, Choimes A, Collen B and others 2015. Global effects of land use on local terrestrial biodiversity. Nature 520 (7545): 45-50.

Nogué S, Whicher K, Baker AG, Bhagwat S, Willis KJ. 2016. Phytolith analysis reveals the intensity of past land use change in the Western Ghats biodiversity hotspot. Quat Int. doi:10. 1016/j.quaint.2015.11.113.

Penne C, Ahrends B, Deurer M, Böttcher J. 2010. The impact of the canopy structure on the spatial variability in forest floor carbon stocks. Geoderma 158:282-97.

Pimm SL, Raven P. 2000. Biodiversity: extinction by numbers. Nature 403(6772):843-5.

Ranganathan J, Daniels RJR, Chandran MDS, Ehrlich PR, Daily GC. 2008. Sustaining biodiversity in ancient tropical countryside. Proc Natl Acad Sci 105:17852-4.

Reimer PJ, Bard E, Bayliss A, Beck JW, Blackwell PG, Bronk Ramsey C, Buck CE, Cheng H, Edwards RL, Friedrich M, Grootes PM, Guilderson TP, Haflidason H, Hajdas I, Hatté C, Heaton TJ, Hoffmann DL, Hogg AG, Hughen KA, Kaiser KF, Kromer B, Manning SW, Niu M, Reimer RW, Richards DA, Scott EM, Southon JR, Staff RA, Turney CSM, van der Plicht J. 2013. IntCall3 and Marinel3 radiocarbon age calibration curves 0-50,000 years cal BP. Radiocarbon 55(4):1869-87.

Ricketts TH, Regetz J, Steffan-Dewenter I, Cunningham SA, Kremen C, Bogdanski A, Gemmill-Herren B, Greenleaf SS, Klein AM, Mayfield MM, Morandin LA, Ochieng A, Viana BF. 2008. Landscape effects on crop pollination services: Are there general patterns? Ecol Lett 11:499-515.

Svenning JC. 2002. A review of natural vegetation openness in north-west Europe. Biol Conserv 104:133-48.

Swetnam TW, Allen CD, Betancourt JL. 1999. Applied historical ecology: using the past to manage for the future. Ecol Appl 9:1189-206.

ter Braak CJFT. 1986. Canonical correspondence analysis: a new eigenvector technique for multivariate direct gradient analysis. Ecology 67:1167-79.

Tscharntke T, Clough Y, Bhagwat SA, Buchori D, Faust H, Hertel D, Hölscher D, Juhrbandt J, Kessler M, Perfecto I, Scherber C, Schroth G, Veldkamp E, Wanger TC. 2011. Multifunctional shade-tree management in tropical agroforestry landscapes-a review. J Appl Ecol 48(3):619-29.

Whitlock C, Larsen C. 2001. Charcoal as a fire proxy. In: Smol JP, Birks HJB, Last WM, Eds. Tracking environmental change using lake sediments. Dordrecht: Springer.

Willis KJ, Birks HJB. 2006. What is natural? The need for a longterm perspective in biodiversity conservation. Science 314:1261-5.

Wilmshurst JM, Moar NT, Wood JR, Bellingham EJ, Findlater AM, Robinson JJ, Sonte C. 2014. Pollen and ancient DNA provide conservation baselines for offshore islands in New Zealand. Conserv Biol 28(1):202-12. 